\title{
Does the Quality of Valencia Orange Vary in Response to Different Coatings during Cold Storage?
}

\author{
Emad. H. Khedr
}

Department of Pomology, Faculty of Agriculture, Cairo University, Cairo, Egypt.

\begin{abstract}
D UE to the importance of the process of fruit waxing in Valencia orange especially for exportation, the current study aimed to evaluate the effect of bee wax, gum arabic, paraffin oil and chitosan in different concentrations as coating materials on the quality of Valencia orange fruits during cold storage at $5^{\circ} \mathrm{C}$ and $90-95 \%$ relative humidity for 90 days. Chitosan at 1 or $2 \%$ and paraffin at $99 \%$ showed the lowest significant decay percentages. Moreover, chitosan at $2 \%$ showed the lowest rates of weight loss and pectin methylesterase activity, also it maintaining fruit colour brightness and hardness of fruits compared with uncoated ones. In addition to, the different applied films affected significantly respiration rate and ascorbic acid content compared with untreated ones.
\end{abstract}

Keywords : Waxing, Bee wax, Gum arabic, Paraffin oil, Chitosan.

\section{Introduction}

Orange fruits are of great nutritional and commercial importance in Egypt as they are considered one of the most important exported fruit crops, especially cv. Valencia because of its competitive benefit.

One of the major obstacles challenged by the traders during handling and supply of the fruits over long distances from the farms to the markets is maintaining the quality of the fruits. Fruits and vegetables surfaces have natural surfaces waxes that keep harvested products against water evaporation, this natural wax on citrus can be washed or distressed during preparing fruit before packing (Manzano and Diaz, 2001).

The application of fruit coating is considered one of several treatments advanced to reduce post harvest losses and to prolong storage life of fruits. Exterior coating has been used as defense technique for fruits and vegetables (Baldwin et al., 1995). The main objectives of the application of fruit coating are to reduce the water evaporation from the fruits, and by this means decrease of weight loss, Baldwin et al., (1999) reported that coating can decrease fruit weight loss by up to $50 \%$, and it can maintain the quality of the fruits. Many previous reports have been focused on waxes coating on different fruits (Saftner, 1999, Shein et al., 2008 and El-Anany et al., 2009).
McGuire (1997) reported that waxing reduce oxygen and increase $\mathrm{CO}_{2}$ level significantly, and waxed fruit maintain better physical appearance but showed sharpest degradation in distinguished taste, also waxes used to enhance the brightness to improve appearance.

However, many of the commercial coatings are criticized because its composition, recently consumers have concerned for healthy and safe products, that need follow up and evaluation for different alternatives (Porta et al., 2013).

Chitosan is a high molecular weight, it is an effective antioxidant capable of retaining vitamin $\mathrm{C}$ in fruit, and it has bacteriostatic and bactericidal possessions. So that, chitosan is a highly recommended polymer for the production of edible film coatings (Tendaj and Tendaj, 1998).

Paraffin waxes are hydrocarbons, mixture of alkanes usually in a homologous series of chain lengths, paraffin waxes were used in wide range but it has a side effect on fruit shine (Salman et al., 2008). Also, bee wax coatings were applied in some fruits (Shahid and Abbasi, 2011).

Gum arabic is a dried, gummy exudate from the stems or branches of Acacia species. It is the least gelatinous and most soluble of the hydrocolloids, and is used widely in the industrial purposes in regard to its emulsification, film forming and encapsulation characteristics (Motlagh et al., 2006). 
The aim of this study is to distinguish the effects of some coating applications such as chitosan, paraffin, bee waxes and gum arabic on the quality changes, both physically and chemically of Valencia orange fruits and to compare the efficiency of these different coatings for maintaining quality of Valencia orange fruits during cold storage.

\section{Materials and Methods}

The present study was applied in two successive seasons (2016 and 2017), orange (Citrus sinensis L.) fruits of $\mathrm{cv}$. Valencia were hand harvested at the ripening stage according to indices that mentioned by Kader (1992) from a commercial orchard located in El-Behira governorate, Egypt. Valencia orange trees were about 8 years old, grafted on Volkamer lemon (Citrus volkameriana) rootstock and planted in a sandy soil at 4 X 6 meters under drip irrigation system and subjected to all ideal agricultural practices.

Fruits were selected to be similar in size and skin colour, and free of any observable pathological defects or mechanical damage. Fruits were washed before treatments by distilled water, after that were dipped in hot water at $40^{\circ} \mathrm{C}$ for 3 min as a quarantine treatment (Kader, 1992), fruits were randomly divided into nine treatment groups.

\section{Coating treatments}

- Control group fruits (untreated).

- $\quad$ Fruits coated with bee wax 10\%.

- $\quad$ Fruits coated with bee wax $15 \%$.

- $\quad$ Fruits coated with gum arabic 5\%.

- $\quad$ Fruits coated with gum arabic $10 \%$.

- $\quad$ Fruits coated with chitosan 1\%.

- $\quad$ Fruits coated with chitosan $2 \%$.

- $\quad$ Fruits coated with paraffin oil $75 \%$.

- $\quad$ Fruits coated with paraffin oil 99\%.

\section{Coating preparation}

Different coatings prepared as follow, bee wax was prepared in two concentrations 10 and $15 \%$, the wax emulsion was prepared by dissolving bee wax (100 and $150 \mathrm{~g}$, depends on the concentration) into $1000 \mathrm{ml}$ water phase. The water phase was heated to the temperature of $90^{\circ} \mathrm{C}$, until all wax was became completely hydrated according to Hassan et al. (2014).

Gum arabic solutions (5 or $10 \%$ w/v) were prepared by dissolving gum arabic in distilled water and heated at $40^{\circ} \mathrm{C}$ according to the method described by Asgar et al. (2010), with continuous stirring for $60 \mathrm{~min}$ on a magnetic stirrer hot plate until the solution became clear, the $\mathrm{pH}$ of the solution was maintained at 5.6 using $1 \mathrm{~N} \mathrm{NaOH}$.

Chitosan ( 1 and $2 \% \mathrm{w} / \mathrm{v})$ were dispersed in an aqueous solution of glacial acetic acid (1\% $\mathrm{v} / \mathrm{v}$ ) according to Miranda et al. (2004), $\mathrm{pH}$ was adjusted to 5.2 using $1 \mathrm{~N} \mathrm{NaOH}$, the stock solution was sterilized at $121^{\circ} \mathrm{C}$ for $20 \mathrm{~min}$.

Paraffin oil (75 and 99\%) was of chemical grade (El-Gomhouria Co., Al Ameria - Cairo, Egypt) and applied with the procedure that mentioned by El-Anany et al. (2009).

Coating treatments were applied by immersing the fruits in the prepared coating materials for 5 min, the coating solution was applied uniformly on the whole fruit surface, while control fruits were dipped in water for the same time.

Then all fruits were air dried, divided in groups for weight loss evaluation, decay follow up, and sampling for physical and chemical analysis, and packed in cartoon boxes and stored at $5^{\circ} \mathrm{C}$ and 90 $95 \% \mathrm{RH}$ for 90 days. Data were recorded before treatment and at 15 days intervals using five fruits from each replicate (three replicates) of each treatment.

\section{Fruit physical properties}

- Weight loss percentage was calculated using the following equation, (fruit initial weight - fruit weight at each sampling date) / fruit initial weight $\mathrm{x} 100$.

- Decay fruit percentage was calculated as number of discarded fruits / total number of fruits x 100, discarded fruits included any signs of pathological, physiological disorders or chilling injury.

- Fruit firmness was determined according to Mitcham et al. (2003) using fruit pressure tester ( $8 \mathrm{~mm}$ diameter probe) on the opposite surfaces of each fruit, data was presented as lb/inch ${ }^{2}$.

- Instrumental colour was measured in the CIE $\mathrm{L}^{*} \mathrm{a}^{*} \mathrm{~b}^{*}$ on two opposite sides of fruit objectively using a Minolta CR-400 chroma meter (Minolta, Osaka, Japan) according to McGuire (1992).

- Respiration rate as $\mathrm{ml}$ of $\mathrm{CO}_{2} / \mathrm{kg} / \mathrm{hr}$ was measured by gas chromatography (Model 1450-Servomex 1400), fruits were stored in airtight glass jars for $24 \mathrm{hr}$ at the same experimental conditions according to McCollum et al. (1993). 


\section{Fruit chemical properties}

- Ascorbic acid was measured using titration method against 2,6 dicholorophenol indophenol solution, results were expressed as $\mathrm{mg}$ ascorbic acid per $100 \mathrm{~g} \mathrm{FW}$ (Mazumdar and Majumder, 2003).

- Total soluble solids / acid ratio calculated using TSS and acidity data, TSS was assessed by refractometer using drops of the fruit juice, total acidity was measured by titration method (A.O.A.C. 1980) and expressed as percentage of the dominant acid in the fruit (citric acid).

- Pectin methylesterase activity (PME, E.C. 3.1.1.11) was defined as $\Delta \mathrm{A} 620 \mathrm{mg}^{-1}$ protein $\min ^{-1}$, the method was in accordance with that described by Jeong et al. (2002) using $101 \mathrm{M}$ potassium phosphate as extract buffer, the reaction was initiated by addition of 6 $\mu \mathrm{L}$ of the cell free protein extract $(\mathrm{pH} 7.5)$, decrement in A620 over a reaction time (10 min) was recorded.
The treatments were involved in a factorial experiment arranged in randomized complete block design with three replicates. The treatments means were compared based on the method of LSD at the 5\% level of significance (Snedecor and Cochran, 1989).

\section{Results and Discussion}

\section{Fruit physical properties}

\section{Weight loss percentage}

Tables 1 and 2 show the effect of different coatings on weight loss $(\%)$ of Valencia orange fruits during cold storage at $5^{\circ} \mathrm{C}$ in 2016 and 2017 seasons, weight loss (\%) increased continually under all circumstances in both seasons. In the first season, untreated fruits showed the highest significant weight loss value, on the other hand fruits treated with $2 \%$ chitosan, $99 \%$ paraffin or $5 \%$ gum arabic showed the lowest significant weight loss values.

TABLE 1. Effect of different coatings on weight loss (\%) of Valencia orange fruits during cold storage at $5^{\circ} \mathrm{C}$ in 2016 season.

\begin{tabular}{|c|c|c|c|c|c|c|c|c|}
\hline \multirow{2}{*}{ Treatment (A) } & \multicolumn{7}{|c|}{ Days of storage at $5^{\circ} \mathrm{C}$ (B) } & \multirow{2}{*}{ Mean } \\
\hline & $\mathbf{0}$ & 15 & 30 & 45 & 60 & 75 & 90 & \\
\hline $10 \%$ Bee wax & 0.00 & 0.84 & 1.30 & 2.22 & 2.78 & 3.73 & 4.54 & 2.20 \\
\hline $15 \%$ Bee wax & 0.00 & 0.66 & 1.09 & 2.03 & 2.56 & 3.43 & 4.29 & 2.01 \\
\hline $5 \%$ Gum arabic & 0.00 & 0.63 & 0.98 & 1.80 & 2.29 & 3.00 & 3.69 & 1.77 \\
\hline $10 \%$ Gum arabic & 0.00 & 0.64 & 1.09 & 1.91 & 2.41 & 3.16 & 3.86 & 1.87 \\
\hline $1 \%$ Chitosan & 0.00 & 0.64 & 1.03 & 1.83 & 2.41 & 3.26 & 3.99 & 1.88 \\
\hline $2 \%$ Chitosan & 0.00 & 0.62 & 0.98 & 1.73 & 2.24 & 3.01 & 3.71 & 1.76 \\
\hline $75 \%$ Paraffin & 0.00 & 0.72 & 1.20 & 2.10 & 2.74 & 3.65 & 4.46 & 2.13 \\
\hline 99\% Paraffin & 0.00 & 0.63 & 1.00 & 1.71 & 2.23 & 3.03 & 3.73 & 1.76 \\
\hline Control & 0.00 & 0.85 & 1.37 & 2.30 & 2.96 & 3.92 & 4.75 & 2.31 \\
\hline Mean & 0.00 & 0.69 & 1.12 & 1.96 & 2.51 & 3.35 & 4.11 & \\
\hline L.S.D ${ }^{0.05}$ & \multicolumn{8}{|c|}{$(A)=0.21,(B)=0.18,(A \times B)=0.55$} \\
\hline
\end{tabular}

TABLE 2. Effect of different coatings on weight loss (\%) of Valencia orange fruits during cold storage at $5^{\circ} \mathrm{C}$ in 2017 season.

\begin{tabular}{lcccccccc}
\hline & \multicolumn{7}{c}{ Days of storage at $\mathbf{5}^{\circ} \mathbf{C}(\mathbf{B})$} & Mean \\
\cline { 2 - 8 } Treatment (A) & $\mathbf{0}$ & $\mathbf{1 5}$ & $\mathbf{3 0}$ & $\mathbf{4 5}$ & $\mathbf{6 0}$ & $\mathbf{7 5}$ & $\mathbf{9 0}$ & \\
\hline 10\% Bee wax & 0.00 & 0.71 & 1.26 & 2.25 & 2.82 & 3.69 & 4.52 & 2.18 \\
15\% Bee wax & 0.00 & 0.75 & 1.16 & 2.16 & 2.72 & 3.59 & 4.49 & 2.12 \\
5\% Gum arabic & 0.00 & 0.71 & 1.09 & 2.00 & 2.54 & 3.48 & 4.18 & 2.00 \\
10\% Gum arabic & 0.00 & 0.72 & 1.13 & 2.01 & 2.56 & 3.44 & 4.22 & 2.01 \\
1\% Chitosan & 0.00 & 0.74 & 1.07 & 1.99 & 2.51 & 3.38 & 4.07 & 1.97 \\
2\% Chitosan & 0.00 & 0.67 & 1.06 & 1.71 & 2.26 & 3.12 & 3.72 & 1.79 \\
75\% Paraffin & 0.00 & 0.81 & 1.22 & 2.15 & 2.82 & 3.69 & 4.56 & 2.18 \\
99\% Paraffin & 0.00 & 0.62 & 0.96 & 1.79 & 2.37 & 3.11 & 3.78 & 1.80 \\
Control & 0.00 & 0.95 & 1.49 & 2.50 & 3.12 & 4.11 & 5.03 & 2.46 \\
Mean & 0.00 & 0.74 & 1.16 & 2.06 & 2.64 & 3.51 & 4.29 & \\
L.S.D ${ }^{0.05}$ & $(\mathrm{~A})=0.18,(\mathrm{~B})=0.16,(\mathrm{~A} \times \mathrm{B})=0.47$ & & & & \\
\hline
\end{tabular}


At the end of storage period, untreated fruits recorded the highest significant percentage (4.75\%), whereas gum arabic at 5\% treatment recorded the lowest significant value (3.69\%).

In the second season, control showed the highest significant mass loss value, on the contrary fruits treated with 2\% chitosan and $99 \%$ paraffin showed the lowest significant values. At the end of storage period, untreated fruits recorded the highest significant loss (5.03\%), whereas chitosan at $2 \%$ treatment recorded $3.72 \%$ that was the lowest significant value.

These results are in harmony with those mentioned by Miranda et al. (2004) who reported that $2 \%$ chitosan films reduced water evaporation rate significantly. Post harvest water loss from fresh fruits is a serious problem, causing shrinkage and mass loss. Surface coatings have been used commonly in fruits to reduce water loss, avoid the shriveling of the fruit skin, delay the fruit ripening, and thus delay the deterioration. The fruit weight decrease due to its respiratory processes, oxidation, and the evaporation of moisture. The procedure of coating adhering thin film of the coating material to the surface of the fruit. These coats can act as a semi permeable barrier against oxygen, carbon dioxide, moisture and solute movements. Therefore, they can reduce the rates of water loss (Baldwin et al., 1999). The time required for water loss or evaporation depends on the temperature, fruit storage period, and the thickness of the fruit peel. Evaporation and respiration may be the main reason for high weight loss percent in untreated fruits (Park, 1999). Under conditions of this experiment, chitosan at $2 \%$ was the most effective coating in maintaining fruit water content.

\section{Decay fruit percentage}

Tables 3 and 4 declare the effect of different coating materials on decay (\%) of Valencia orange fruits during cold storage at $5^{\circ} \mathrm{C}$ in 2016 and 2017 seasons, decay fruit percentage increased gradually with prolongation cold storage, in the first season, untreated fruits showed the highest significant deterioration, on the other hand fruits treated by chitosan at 2 or $1 \%$ and paraffin at $99 \%$ showed the lowest significant values. After 90 days, untreated fruits recorded $24.44 \%$ that was the highest significant percentage, whereas $2 \%$ chitosan treatment recorded the lowest decay percentage $(3.33 \%)$.

TABLE 3. Effect of different coatings on decay (\%) of Valencia orange fruits during cold storage at $5^{\circ} \mathrm{C}$ in 2016 season.

\begin{tabular}{|c|c|c|c|c|c|c|c|c|}
\hline \multirow{2}{*}{ Treatment (A) } & \multicolumn{7}{|c|}{ Days of storage at $5^{\circ} \mathrm{C}$ (B) } & \multirow{2}{*}{ Mean } \\
\hline & $\mathbf{0}$ & 15 & 30 & 45 & 60 & 75 & 90 & \\
\hline $10 \%$ Bee wax & 0.00 & 0.00 & 0.00 & 1.11 & 3.33 & 6.10 & 9.44 & 2.85 \\
\hline $15 \%$ Bee wax & 0.00 & 0.00 & 0.00 & 2.22 & 2.77 & 4.99 & 8.33 & 2.62 \\
\hline $5 \%$ Gum arabic & 0.00 & 0.00 & 0.00 & 1.11 & 2.22 & 3.88 & 7.22 & 2.06 \\
\hline $10 \%$ Gum arabic & 0.00 & 0.00 & 0.00 & 0.00 & 1.66 & 5.55 & 6.10 & 1.90 \\
\hline 1\% Chitosan & 0.00 & 0.00 & 0.00 & 0.00 & 0.00 & 3.33 & 4.44 & 1.11 \\
\hline $2 \%$ Chitosan & 0.00 & 0.00 & 0.00 & 0.00 & 0.00 & 2.77 & 3.33 & 0.87 \\
\hline $75 \%$ Paraffin & 0.00 & 0.00 & 0.00 & 0.00 & 1.66 & 5.55 & 6.10 & 1.90 \\
\hline 99\% Paraffin & 0.00 & 0.00 & 0.00 & 0.00 & 0.44 & 3.88 & 5.55 & 1.41 \\
\hline Control & 0.00 & 1.11 & 1.66 & 4.44 & 7.77 & 9.99 & 24.44 & 7.06 \\
\hline Mean & 0.00 & 0.12 & 0.18 & 0.99 & 2.21 & 5.12 & 8.33 & \\
\hline L.S.D ${ }^{0.05}$ & \multicolumn{8}{|c|}{$(A)=0.74,(B)=0.65,(A \times B)=1.95$} \\
\hline
\end{tabular}

In the second season, untreated fruits showed the highest significant value, on the other hand fruits treated by $2 \%$ chitosan or $1 \%$ chitosan and $99 \%$ paraffin showed the lowest significant percentages.

At the end of storage period, untreated fruits recorded the highest significant decay percentage $25.55 \%$, whereas $2 \%$ chitosan and $1 \%$ chitosan treatments recorded the lowest significant values $3.88 \%$ and $4.99 \%$ respectively.

Egypt. J. Hort. Vol. 44, No.2 (2017)
The obtained results declared that chitosan at both studied concentrations were helpful in decreasing fruit deterioration. Moreover, these findings are supported by El-Anany et al. (2009) who noted that the application of edible coating in combination with cold storage $\left(0^{\circ} \mathrm{C}\right)$ on apple cv. Anna can reduce decay percentage occurrence of about 1.5 to 3.0 times compared with control. Hassan et al. (2014) reported that the effect of coating on fruit decay percentage is vary depending on coating film thickness, 
whereas thin coat may be not effective in reducing deterioration, while copious coat may induce fruit rot and finally induce fruit off-flavour.

The usage of edible coatings moderately limit gas exchange through the fruit and obstruct the action of ethylene. This inhibitory action can provide effective fruits protection. Additionally, coating may cure minor wounds on the surface of the fruits and thus reduce fruit rots (Tietel et al., 2010).

TABLE 4. Effect of different coatings on decay (\%) of Valencia orange fruits during cold storage at $5^{\circ} \mathrm{C}$ in 2017 season.

\begin{tabular}{|c|c|c|c|c|c|c|c|c|}
\hline \multirow[b]{2}{*}{ Treatment (A) } & \multicolumn{7}{|c|}{ Days of storage at $5^{\circ} \mathrm{C}$ (B) } & \multirow[b]{2}{*}{ Mean } \\
\hline & $\mathbf{0}$ & 15 & 30 & 45 & 60 & 75 & 90 & \\
\hline $10 \%$ Bee wax & 0.00 & 0.00 & 0.00 & 1.66 & 3.33 & 7.22 & 9.44 & 3.09 \\
\hline $15 \%$ Bee wax & 0.00 & 0.00 & 0.00 & 2.22 & 2.77 & 6.10 & 8.88 & 2.85 \\
\hline $5 \%$ Gum arabic & 0.00 & 0.00 & 0.00 & 1.11 & 2.22 & 4.99 & 7.77 & 2.30 \\
\hline $10 \%$ Gum arabic & 0.00 & 0.00 & 0.00 & 0.55 & 2.77 & 5.55 & 6.66 & 2.22 \\
\hline 1\% Chitosan & 0.00 & 0.00 & 0.00 & 0.00 & 0.55 & 3.33 & 4.99 & 1.27 \\
\hline $2 \%$ Chitosan & 0.00 & 0.00 & 0.00 & 0.00 & 0.55 & 3.44 & 3.88 & 1.12 \\
\hline $75 \%$ Paraffin & 0.00 & 0.00 & 0.00 & 0.55 & 1.66 & 6.10 & 6.66 & 2.14 \\
\hline 99\% Paraffin & 0.00 & 0.00 & 0.00 & 0.00 & 0.55 & 4.44 & 5.55 & 1.51 \\
\hline Control & 0.00 & 1.66 & 2.22 & 6.11 & 7.77 & 10.55 & 25.55 & 7.69 \\
\hline Mean & 0.00 & 0.18 & 0.25 & 1.36 & 2.47 & 5.75 & 8.82 & \\
\hline L.S.D ${ }^{0.05}$ & \multicolumn{8}{|c|}{$(A)=0.73,(B)=0.64,(A \times B)=1.94$} \\
\hline
\end{tabular}

\section{Fruit firmness (lb/inch $\left.{ }^{2}\right)$}

Tables 5 and 6. illustrate the effect of different coatings on Valencia orange firmness during cold storage at $5^{\circ} \mathrm{C}$ in 2016 and 2017 seasons. The data revealed that firmness decreased gradually in both seasons with the progress of storage period.
Chitosan at $2 \%$, paraffin at $99 \%$ and gum arabic at $5 \%$ showed the highest significant values of firmness in the first season, whereas chitosan at $2 \%$ only gave the highest value in the second one, on the other hand, control showed the lowest significant values in both seasons.

TABLE 5. Effect of different coatings on firmness $\left(\mathrm{lb} / \mathrm{inch}^{2}\right)$ of Valencia orange fruits during cold storage at $5^{\circ} \mathrm{C}$ in 2016 season.

\begin{tabular}{|c|c|c|c|c|c|c|c|c|}
\hline \multirow{2}{*}{ Treatment (A) } & \multicolumn{7}{|c|}{ Days of storage at $5^{\circ} \mathrm{C}$ (B) } & \multirow{2}{*}{ Mean } \\
\hline & $\mathbf{0}$ & 15 & 30 & 45 & 60 & 75 & 90 & \\
\hline $10 \%$ Bee wax & 18.64 & 17.74 & 17.68 & 17.40 & 17.34 & 17.22 & 16.79 & 17.55 \\
\hline $15 \%$ Bee wax & 18.64 & 17.78 & 17.71 & 17.68 & 17.54 & 17.44 & 16.98 & 17.68 \\
\hline $5 \%$ Gum arabic & 18.64 & 17.89 & 17.87 & 17.79 & 17.69 & 17.53 & 17.39 & 17.83 \\
\hline $10 \%$ Gum arabic & 18.64 & 17.93 & 17.85 & 17.81 & 17.73 & 17.67 & 16.90 & 17.79 \\
\hline 1\% Chitosan & 18.64 & 17.86 & 17.79 & 17.70 & 17.57 & 17.38 & 17.33 & 17.75 \\
\hline 2\% Chitosan & 18.64 & 18.01 & 17.94 & 17.88 & 17.81 & 17.77 & 17.19 & 17.89 \\
\hline $75 \%$ Paraffin & 18.64 & 17.82 & 17.75 & 17.63 & 17.50 & 17.16 & 16.82 & 17.62 \\
\hline 99\% Paraffin & 18.64 & 17.88 & 17.85 & 17.75 & 17.69 & 17.59 & 17.49 & 17.84 \\
\hline Control & 18.64 & 17.11 & 17.03 & 16.91 & 16.61 & 16.11 & 15.46 & 16.84 \\
\hline Mean & 18.64 & 17.78 & 17.72 & 17.62 & 17.50 & 17.32 & 16.93 & \\
\hline L.S.D ${ }^{0.05}$ & $(\mathrm{~A})=$ & $(\mathrm{B})=$ & $(A \times B)$ & .37 & & & & \\
\hline
\end{tabular}

At the end of storage period paraffin at $99 \%$ treatment showed the highest significant firmness value $\left(17.49 \mathrm{lb} /\right.$ inch $\left.^{2}\right)$, whereas control treatments showed the lowest hardness $\left(15.46 \mathrm{lb} /\right.$ inch $\left.^{2}\right)$ in the first season. While in the second one, chitosan $2 \%$ treatment showed the highest significant value $\left(15.71 \mathrm{lb} /\right.$ inch $\left.^{2}\right)$, whereas untreated fruits showed the lowest significant firmness $\left(12.36 \mathrm{lb} / \mathrm{inch}^{2}\right)$.
Fruit hardness is considered as one of the main quality characteristics and considered one of the limiting post-harvest life. Results showed that there was a significant difference in fruit firmness between different coatings. These results are in conformity with those mentioned by Chien et al. (2007) who found valuable effect of coating on citrus fruits compared with untreated ones. 
Coatings can be act as barrier representative and inhibit water loss from fruits peel that decrease cell wall decomposition and maintain fruit firmness (Del-Valle et al. 2005).

TABLE 6. Effect of different coatings on firmness $\left(\mathrm{lb} / \mathrm{inch}^{2}\right)$ of Valencia orange fruits during cold storage at $5^{\circ} \mathrm{C}$ in 2017 season.

\begin{tabular}{|c|c|c|c|c|c|c|c|c|}
\hline \multirow{2}{*}{ Treatment (A) } & \multicolumn{7}{|c|}{ Days of storage at $5^{\circ} \mathrm{C}$ (B) } & \multirow{2}{*}{ Mean } \\
\hline & $\mathbf{0}$ & 15 & 30 & 45 & 60 & 75 & 90 & \\
\hline $10 \%$ Bee wax & 18.73 & 17.20 & 17.16 & 16.57 & 16.12 & 15.73 & 14.86 & 16.62 \\
\hline $15 \%$ Bee wax & 18.73 & 17.33 & 17.27 & 16.88 & 16.11 & 15.85 & 14.93 & 16.73 \\
\hline $5 \%$ Gum arabic & 18.73 & 17.78 & 17.63 & 17.22 & 16.66 & 16.01 & 15.52 & 17.08 \\
\hline $10 \%$ Gum arabic & 18.73 & 17.82 & 17.72 & 17.24 & 16.63 & 16.10 & 15.64 & 17.13 \\
\hline $1 \%$ Chitosan & 18.73 & 17.62 & 17.53 & 17.06 & 16.45 & 16.07 & 15.08 & 16.93 \\
\hline $2 \%$ Chitosan & 18.73 & 17.87 & 17.81 & 17.32 & 16.79 & 16.23 & 15.71 & 17.21 \\
\hline $75 \%$ Paraffin & 18.73 & 17.56 & 17.36 & 16.95 & 16.14 & 15.85 & 15.05 & 16.80 \\
\hline $99 \%$ Paraffin & 18.73 & 17.74 & 17.43 & 17.11 & 16.52 & 16.03 & 15.22 & 16.97 \\
\hline Control & 18.73 & 16.50 & 15.45 & 15.05 & 14.09 & 12.67 & 12.36 & 14.98 \\
\hline Mean & 18.73 & 17.49 & 17.26 & 16.82 & 16.17 & 15.62 & 14.93 & \\
\hline L.S.D ${ }^{0.05}$ & \multicolumn{8}{|c|}{$(A)=0.12,(B)=0.11,(A \times B)=0.32$} \\
\hline
\end{tabular}

Ali et al. (2004) mentioned that the decrease in firmness detected as fruits ripen concerning a consequence of changes on cell wall metabolism, the softening process is thought to be a result of pectin methyl esterase (PME) followed by polygalacturonase (PG) activity (Abu-Goukh and Bashir, 2003). Moreover that, the higher humidity maintained by these coatings aids in reducing the water loss and respiration activity and thus maintained cell turgidity.
Instrumental colour

Data in Tables 7 and 8 declare the effect of different coatings on $\mathrm{C}$ colour of Valencia orange fruits during cold storage at $5^{\circ} \mathrm{C}$ in 2016 and 2017 seasons, $\mathrm{C}$ colour value increased in the first 30 days then it decreased continuously, chitosan at $2 \%$ showed the highest significant values, whereas paraffin at $75 \%$ showed the lowest significant values in both seasons.

TABLE 7. Effect of different coatings on $\mathrm{C}$ colour value of Valencia orange fruits during cold storage at $5^{\circ} \mathrm{C}$ in 2016 season.

\begin{tabular}{|c|c|c|c|c|c|c|c|c|}
\hline \multirow{2}{*}{ Treatment (A) } & \multicolumn{7}{|c|}{ Days of storage at $5^{\circ} \mathrm{C}$ (B) } & \multirow{2}{*}{ Mean } \\
\hline & $\mathbf{0}$ & 15 & 30 & 45 & 60 & 75 & 90 & \\
\hline $10 \%$ Bee wax & 74.76 & 76.41 & 78.11 & 74.74 & 73.26 & 72.76 & 71.76 & 74.54 \\
\hline $15 \%$ Bee wax & 74.76 & 76.92 & 79.09 & 75.52 & 75.05 & 74.95 & 74.80 & 75.87 \\
\hline $5 \%$ Gum arabic & 74.76 & 76.96 & 79.16 & 76.68 & 75.65 & 74.65 & 72.65 & 75.79 \\
\hline 1\% Chitosan & 74.76 & 76.00 & 77.25 & 77.53 & 75.68 & 74.82 & 74.48 & 75.79 \\
\hline 2\% Chitosan & 74.76 & 74.48 & 74.20 & 78.60 & 77.34 & 77.14 & 76.27 & 76.11 \\
\hline $75 \%$ Paraffin & 74.76 & 74.20 & 73.66 & 74.16 & 74.06 & 73.90 & 73.26 & 74.00 \\
\hline 99\% Paraffin & 74.76 & 77.11 & 79.46 & 74.71 & 74.44 & 73.92 & 73.50 & 75.41 \\
\hline L.S.D ${ }^{0.05}$ & \multicolumn{8}{|c|}{$(A)=0.21,(B)=0.19,(A \times B)=0.57$} \\
\hline
\end{tabular}

At the end of storage period in the first season, chitosan at $2 \%$ exhibited the highest significant $\mathrm{C}$ score (76.27), whereas bee wax at $10 \%$ exhibited the lowest significant $\mathrm{C}$ value (71.76).
At the end of storage period in the second season, $2 \%$ chitosan treatment showed the highest significant value (75.82), whereas control showed the lowest significant value (71.85). 
TABLE 8. Effect of different coatings on $\mathrm{C}$ colour value of Valencia orange fruits during cold storage at $5^{\circ} \mathrm{C}$ in 2017 season.

\begin{tabular}{lcccccccc}
\hline \multirow{2}{*}{ Treatment (A) } & \multicolumn{7}{c}{ Days of storage at $\mathbf{5}^{\circ} \mathbf{C}(\mathbf{B})$} & Mean \\
\cline { 2 - 7 } & $\mathbf{0}$ & $\mathbf{1 5}$ & $\mathbf{3 0}$ & $\mathbf{4 5}$ & $\mathbf{6 0}$ & $\mathbf{7 5}$ & $\mathbf{9 0}$ & \\
\hline 10\% Bee wax & 75.68 & 76.58 & 77.49 & 74.63 & 73.52 & 72.78 & 72.24 & 74.70 \\
15\% Bee wax & 75.68 & 76.47 & 77.27 & 75.56 & 75.11 & 74.91 & 74.30 & 75.61 \\
5\% Gum arabic & 75.68 & 77.11 & 78.56 & 76.67 & 75.67 & 74.64 & 74.16 & 76.07 \\
10\% Gum arabic & 75.68 & 77.66 & 79.67 & 76.86 & 75.30 & 74.79 & 74.48 & 76.35 \\
1\% Chitosan & 75.68 & 76.48 & 77.29 & 77.43 & 75.61 & 74.84 & 74.41 & 75.96 \\
2\% Chitosan & 75.68 & 76.82 & 77.97 & 78.47 & 77.23 & 77.06 & 75.82 & 77.01 \\
$75 \%$ Paraffin & 75.68 & 76.17 & 76.58 & 74.18 & 74.09 & 73.78 & 73.51 & 74.86 \\
99\% Paraffin & 75.68 & 76.76 & 77.85 & 74.75 & 74.54 & 74.05 & 73.60 & 75.32 \\
Control & 75.68 & 77.36 & 78.99 & 74.71 & 73.85 & 73.75 & 71.85 & 75.17 \\
Mean & 75.68 & 76.82 & 77.96 & 75.92 & 74.99 & 74.51 & 73.82 & \\
L.S.D ${ }^{0.05}$ & $(\mathrm{~A})=0.10,(\mathrm{~B})=0.07,(\mathrm{~A} \times \mathrm{B})=0.20$ & & & & \\
\hline
\end{tabular}

Tables 9 and 10 declare the effect of different coating materials on $\mathrm{L}$ colour value in Valencia fruits during cold storage at $5^{\circ} \mathrm{C}$ in both studied seasons, values of L colour increased in the first 15 days then it decreased constantly. Moreover, 2\% chitosan treatment showed the highest significant values, whereas untreated fruits exhibited the lowest significant values.

TABLE 9. Effect of different coatings on $L$ colour value of Valencia orange during cold storage at $5^{\circ} \mathrm{C}$ in 2016 season.

\begin{tabular}{|c|c|c|c|c|c|c|c|c|}
\hline \multirow{2}{*}{ Treatment (A) } & \multicolumn{7}{|c|}{ Days of storage at $5^{\circ} \mathrm{C}$ (B) } & \multirow{2}{*}{ Mean } \\
\hline & $\mathbf{0}$ & 15 & 30 & 45 & 60 & 75 & 90 & \\
\hline $10 \%$ Bee wax & 67.94 & 68.55 & 67.06 & 65.87 & 65.66 & 65.56 & 65.40 & 66.58 \\
\hline $15 \%$ Bee wax & 67.94 & 68.35 & 67.50 & 66.53 & 65.93 & 65.21 & 65.13 & 66.66 \\
\hline $5 \%$ Gum arabic & 67.94 & 68.32 & 66.61 & 64.86 & 64.41 & 63.35 & 62.66 & 65.45 \\
\hline $10 \%$ Gum arabic & 67.94 & 69.02 & 67.42 & 65.83 & 65.45 & 64.63 & 63.94 & 66.32 \\
\hline 1\% Chitosan & 67.94 & 67.04 & 66.79 & 66.67 & 64.48 & 62.46 & 61.34 & 65.25 \\
\hline $2 \%$ Chitosan & 67.94 & 66.76 & 66.34 & 66.92 & 66.82 & 66.63 & 66.16 & 66.80 \\
\hline $75 \%$ Paraffin & 67.94 & 67.79 & 67.12 & 65.20 & 64.59 & 64.54 & 64.37 & 65.94 \\
\hline $99 \%$ Paraffin & 67.94 & 69.75 & 67.93 & 65.85 & 65.22 & 64.53 & 64.14 & 66.48 \\
\hline Control & 67.94 & 69.89 & 68.48 & 65.09 & 62.03 & 60.53 & 60.36 & 64.90 \\
\hline Mean & 67.94 & 68.38 & 67.25 & 65.87 & 64.95 & 64.16 & 63.72 & \\
\hline L.S.D ${ }^{0.05}$ & \multicolumn{8}{|c|}{$(\mathrm{A})=0.24,(\mathrm{~B})=0.21,(\mathrm{~A} \times \mathrm{B})=0.64$} \\
\hline
\end{tabular}

After 3 months of cold storage, 2\% chitosan treatment showed the highest significant $\mathrm{L}$ value (66.16), whereas control recorded the lowest significant value (60.36) in 2016 season, also $2 \%$ chitosan treatment showed the highest significant value (65.68), and control showed the lowest significant L value (60.59) in the second season.

The $\mathrm{L}$ colour value was used as an indicator of brightness, meanwhile chroma presents the quality of a colour's purity and intensity (Nambi et al., 2015). General appearance is an important issue as it reflects the consumer acceptability for fruits, coating affects the peel colour as it add an external layer, and consequently affect the chemical changes in pigments.

According to data, it can be noticed that fruits treated by chitosan had the most shine and appreciable appearance, while those treated with gum arabic and bee wax were darker. Also paraffin treated fruits were greasy shortly after treatment. In general untreated fruits exhibited unacceptable colour shortly, which may be due to the higher metabolism processes. 
TABLE 10. Effect of different coatings on $L$ colour value of Valencia orange during cold storage at $5^{\circ} \mathrm{C}$ in 2017 season.

\begin{tabular}{lcccccccc}
\hline \multirow{2}{*}{ Treatment (A) } & \multicolumn{7}{c}{ Days of storage at $\mathbf{5}^{\circ} \mathbf{C}(\mathbf{B})$} & Mean \\
\cline { 2 - 7 } & $\mathbf{0}$ & $\mathbf{1 5}$ & $\mathbf{3 0}$ & $\mathbf{4 5}$ & $\mathbf{6 0}$ & $\mathbf{7 5}$ & $\mathbf{9 0}$ & \\
\hline 10\% Bee wax & 67.42 & 67.89 & 66.38 & 65.22 & 64.80 & 65.11 & 64.94 & 65.97 \\
15\% Bee wax & 67.42 & 68.02 & 66.86 & 65.90 & 65.17 & 64.76 & 64.61 & 66.11 \\
5\% Gum arabic & 67.42 & 68.04 & 65.97 & 64.23 & 63.65 & 62.91 & 62.26 & 64.92 \\
10\% Gum arabic & 67.42 & 68.73 & 66.77 & 65.17 & 64.66 & 64.18 & 63.47 & 65.77 \\
1\% Chitosan & 67.42 & 66.76 & 66.16 & 66.00 & 63.76 & 61.92 & 60.82 & 64.69 \\
2\% Chitosan & 67.42 & 66.47 & 65.68 & 66.26 & 66.08 & 66.16 & 65.68 & 66.25 \\
75\% Paraffin & 67.42 & 67.49 & 66.48 & 64.52 & 62.72 & 64.10 & 63.89 & 65.23 \\
99\% Paraffin & 67.42 & 69.43 & 67.28 & 65.22 & 64.47 & 64.08 & 63.69 & 65.94 \\
Control & 67.42 & 69.56 & 67.47 & 64.00 & 60.95 & 60.05 & 60.59 & 64.29 \\
Mean & 67.42 & 68.04 & 66.56 & 65.17 & 64.03 & 63.70 & 63.33 & \\
L.S.D ${ }^{0.05}$ & $(\mathrm{~A})=0.30,(\mathrm{~B})=0.26,(\mathrm{~A} \times \mathrm{B})=0.79$ & & & & \\
\hline
\end{tabular}

Mahajan et al., (2005) mentioned that the loss of surface green colour might be associated with the natural ripening process triggered by ethylene, which occurs as the result of chlorophyll molecule breakdown with increase in carotenoids content. Therefore, coating delayed natural metabolic process that accompanied with peel yellowing.

The acceptability of coated fruit is high because the coating maintains the cosmetic appearance of fruits and hence their acceptability, also this may be due to delay in deterioration, uniform colour development in fruits under pure chitosan coating in advanced period of storage. These results also confirmed with the findings of Singh et al. (1997) in guava fruits.

Respiration rate $\left(\mathrm{ml} \mathrm{CO} \mathrm{kg}^{-1} \mathrm{hr}^{-1}\right)$

The effect of different coatings on respiration rate of Valencia orange fruits during cold storage at $5^{\circ} \mathrm{C}$ in 2016 and 2017 seasons is presented in Tables 11. and 12. Respiration rate decreased in the first 15 days then it increased gradually. Control treatment showed the highest significant respiration rate, whereas the differences between the studied treatments were insignificant under all circumstances.

TABLE 11. Effect of different coatings on respiration rate of Valencia orange fruits $\left(\mathrm{ml} \mathrm{CO}_{2} \mathrm{~kg}^{-1} \mathrm{hr}^{-1}\right)$ during cold storage at $5^{\circ} \mathrm{C}$ in 2016 season.

\begin{tabular}{lcccccccc}
\hline \multirow{2}{*}{ Treatment (A) } & \multicolumn{9}{c}{ Days of storage at $\mathbf{5}^{\circ} \mathbf{C}(\mathbf{B})$} & Mean \\
\cline { 2 - 7 } & $\mathbf{0}$ & $\mathbf{1 5}$ & $\mathbf{3 0}$ & $\mathbf{4 5}$ & $\mathbf{6 0}$ & $\mathbf{7 5}$ & $\mathbf{9 0}$ & \multirow{2}{*}{ M } \\
\hline 10\% Bee wax & 4.82 & 3.20 & 3.21 & 3.22 & 3.23 & 3.27 & 3.30 & 3.46 \\
15\% Bee wax & 4.82 & 3.15 & 3.17 & 3.20 & 3.22 & 3.25 & 3.26 & 3.44 \\
5\% Gum arabic & 4.82 & 3.14 & 3.16 & 3.18 & 3.18 & 3.22 & 3.23 & 3.42 \\
10\% Gum arabic & 4.82 & 3.12 & 3.14 & 3.15 & 3.16 & 3.20 & 3.21 & 3.40 \\
1\% Chitosan & 4.82 & 3.16 & 3.18 & 3.19 & 3.24 & 3.28 & 3.33 & 3.46 \\
2\% Chitosan & 4.82 & 3.13 & 3.15 & 3.16 & 3.17 & 3.18 & 3.20 & 3.40 \\
75\% Paraffin & 4.82 & 3.17 & 3.18 & 3.21 & 3.25 & 3.31 & 3.36 & 3.47 \\
99\% Paraffin & 4.82 & 3.13 & 3.13 & 3.14 & 3.19 & 3.21 & 3.23 & 3.41 \\
Control & 4.82 & 3.21 & 3.24 & 3.25 & 3.32 & 3.47 & 4.04 & 3.62 \\
Mean & 4.82 & 3.16 & 3.17 & 3.19 & 3.22 & 3.27 & 3.35 & \\
L.S.D 0.05 & $(\mathrm{~A})=0.12,(\mathrm{~B})=0.10,(\mathrm{~A} \times \mathrm{B})=0.31$ & & & & \\
\hline
\end{tabular}

At the end of storage period, control treatment showed the highest significant respiration rates (4.04 and $4.18 \mathrm{ml} \mathrm{CO}_{2} \mathrm{~kg}^{-1}$ ) in the first and second

Egypt. J. Hort. Vol. 44, No.2 (2017) seasons respectively, whereas the differences between the used treatments were insignificant in both seasons. 
TABLE 12. Effect of different coatings on respiration rate of Valencia orange fruits $\left(\mathrm{ml} \mathrm{CO}_{2} \mathrm{~kg}^{-1} \mathrm{hr}^{-1}\right) \mathrm{during}$ cold storage at $5^{\circ} \mathrm{C}$ in 2017 season.

\begin{tabular}{lcccccccc}
\hline \multirow{2}{*}{ Treatment (A) } & \multicolumn{9}{c}{ Days of storage at $\mathbf{5}^{\circ} \mathbf{C}(\mathbf{B})$} & \multicolumn{1}{c}{ Mean } \\
\cline { 2 - 8 } & $\mathbf{0}$ & $\mathbf{1 5}$ & $\mathbf{3 0}$ & $\mathbf{4 5}$ & $\mathbf{6 0}$ & $\mathbf{7 5}$ & $\mathbf{9 0}$ & 3.58 \\
\hline 10\% Bee wax & 4.96 & 3.23 & 3.27 & 3.34 & 3.40 & 3.41 & 3.43 & 3.51 \\
15\% Bee wax & 4.96 & 3.17 & 3.22 & 3.25 & 3.30 & 3.31 & 3.37 & 3.48 \\
5\% Gum arabic & 4.96 & 3.16 & 3.18 & 3.21 & 3.23 & 3.28 & 3.33 & 3.48 \\
10\% Gum arabic & 4.96 & 3.16 & 3.19 & 3.23 & 3.25 & 3.28 & 3.32 & 3.49 \\
1\% Chitosan & 4.96 & 3.17 & 3.21 & 3.24 & 3.30 & 3.32 & 3.45 & 3.52 \\
2\% Chitosan & 4.96 & 3.16 & 3.18 & 3.21 & 3.23 & 3.25 & 3.28 & 3.47 \\
75\% Paraffin & 4.96 & 3.20 & 3.21 & 3.23 & 3.28 & 3.28 & 3.48 & 3.52 \\
99\% Paraffin & 4.96 & 3.16 & 3.19 & 3.22 & 3.29 & 3.31 & 3.36 & 3.50 \\
Control & 4.96 & 3.29 & 3.36 & 3.74 & 3.77 & 3.81 & 4.18 & 3.87 \\
Mean & 4.96 & 3.19 & 3.22 & 3.30 & 3.34 & 3.36 & 3.47 & \\
L.S.D ${ }^{0.05}$ & $(\mathrm{~A})=0.14,(\mathrm{~B})=0.12,(\mathrm{~A} \times \mathrm{B})=0.36$ & & & & \\
\hline
\end{tabular}

These results are in accordance with those obtained by Porat et al. (2005) in mandarin fruits. Coatings act as semi permeable films that manage the movement of gases and water vapor to reduce the rate of respiration and water loss from the fruit. Many coatings due to their fence and mechanical properties can reduce the rate of physiological postharvest degradation (Baldwin et al., 1999). In other words, coatings reduce gas exchange and resulted in reduction of oxygen and increased $\mathrm{CO}_{2}$ surrounding the fruit (Porat et al., 2005). However, some waxes have been shown to negatively alter the internal atmosphere of the fruit by inducing anaerobic off-flavor (Park, 1999).

The process of coating adhering thin film of the coating substance to the surface of the fruit. These coats can act as a semi permeable barrier against oxygen, carbon dioxide, moisture and solute movements. Therefore, they can reduce the rates of the respiration, water loss and oxidation reaction, The results of this experiment are in line with those illustrated by Baldwin et al. (1999).

\section{Fruit chemical properties}

Ascorbic acid (mg / $100 \mathrm{~g}$ Fresh Weight)

The obtained data of different coatings effect on ascorbic acid content of Valencia orange fruits during cold storage at $5^{\circ} \mathrm{C}$ throughout the both studied seasons were tabulated in Tables 13 and 14. Ascorbic acid decreased gradually with the progress of storage period. The data also revealed that all coating materials markedly maintained vitamin $\mathrm{C}$ content compared to control in both experimental seasons. The differences between the different coating materials were insignificant, but untreated fruits showed lowest significant values compared with treated ones in both seasons.

TABLE 13. Effect of different coatings on ascorbic acid content of Valencia orange fruits (mg / $100 \mathrm{~g}$ FW) during cold storage at $5^{\circ} \mathrm{C}$ in 2016 season.

\begin{tabular}{lcccccccc}
\hline \multirow{2}{*}{ Treatment (A) } & \multicolumn{9}{c}{ Days of storage at $\mathbf{5}^{\circ} \mathbf{C}(\mathbf{B})$} & Mean \\
\cline { 2 - 7 } & $\mathbf{0}$ & $\mathbf{1 5}$ & $\mathbf{3 0}$ & $\mathbf{4 5}$ & $\mathbf{6 0}$ & $\mathbf{7 5}$ & $\mathbf{9 0}$ & \\
\hline 10\% Bee wax & 55.64 & 54.74 & 54.66 & 53.65 & 50.63 & 49.75 & 47.27 & 52.34 \\
15\% Bee wax & 55.64 & 54.78 & 54.71 & 53.69 & 50.73 & 49.80 & 47.35 & 52.38 \\
5\% Gum arabic & 55.64 & 54.89 & 54.85 & 53.37 & 50.60 & 49.67 & 47.21 & 52.32 \\
10\% Gum arabic & 55.64 & 54.93 & 54.91 & 53.51 & 50.40 & 49.77 & 47.60 & 52.40 \\
1\% Chitosan & 55.64 & 54.86 & 54.81 & 53.51 & 51.04 & 49.62 & 47.82 & 52.47 \\
2\% Chitosan & 55.64 & 54.96 & 54.88 & 53.73 & 50.62 & 49.73 & 47.84 & 52.49 \\
75\% Paraffin & 55.64 & 54.82 & 54.79 & 53.50 & 50.68 & 49.77 & 47.56 & 52.39 \\
99\% Paraffin & 55.64 & 54.77 & 54.69 & 53.55 & 50.88 & 49.80 & 47.77 & 52.44 \\
Control & 55.64 & 54.11 & 53.99 & 50.79 & 48.74 & 46.55 & 46.36 & 50.88 \\
Mean & 55.64 & 54.76 & 54.70 & 53.26 & 50.48 & 49.39 & 47.42 & \\
L.S.D & 0.05 & (A) $=0.22,(B)=0.20,(A \times B)=0.59$ & & & & \\
\hline
\end{tabular}


At the end of storage period treatments of chitosan (2 and 1\%) treatments showed the highest significant values 47.84 and $47.82 \mathrm{mg} / 100 \mathrm{~g} \mathrm{FW}$ respectively, whereas control treatment showed the lowest significant ascorbic acid content (46.36 $\mathrm{mg} / 100 \mathrm{~g} \mathrm{FW}$ ) in 2016 season.
The same trend was observed in the second season, where chitosan at 2 and $1 \%$ treatments showed the highest values (48.14 and $48.10 \mathrm{mg}$ / $100 \mathrm{~g} \mathrm{FW}$ ) respectively, however the differences between different coatings were insignificant, while untreated fruits showed the lowest significant content $46.59 \mathrm{mg} / 100 \mathrm{~g} \mathrm{FW}$.

TABLE 14. Effect of different coatings on ascorbic acid content of Valencia orange fruits (mg / $100 \mathrm{~g} \mathrm{FW})$ during cold storage at $5^{\circ} \mathrm{C}$ in 2017 season.

\begin{tabular}{|c|c|c|c|c|c|c|c|c|}
\hline \multirow{2}{*}{ Treatment (A) } & \multicolumn{7}{|c|}{ Days of storage at $5^{\circ} \mathrm{C}$ (B) } & \multirow{2}{*}{ Mean } \\
\hline & $\mathbf{0}$ & 15 & 30 & 45 & 60 & 75 & 90 & \\
\hline $10 \%$ Bee wax & 55.28 & 54.65 & 54.51 & 54.46 & 53.65 & 51.55 & 47.64 & 53.11 \\
\hline $15 \%$ Bee wax & 55.28 & 54.66 & 54.54 & 54.49 & 53.71 & 51.23 & 47.67 & 53.08 \\
\hline $5 \%$ Gum arabic & 55.28 & 54.82 & 54.70 & 54.66 & 54.02 & 51.63 & 47.62 & 53.25 \\
\hline $10 \%$ Gum arabic & 55.28 & 54.92 & 54.80 & 54.73 & 53.99 & 51.72 & 48.00 & 53.35 \\
\hline 1\% Chitosan & 55.28 & 54.80 & 54.72 & 54.51 & 54.63 & 51.68 & 48.10 & 53.39 \\
\hline $2 \%$ Chitosan & 55.28 & 54.89 & 54.82 & 54.75 & 54.14 & 51.68 & 48.14 & 53.39 \\
\hline $75 \%$ Paraffin & 55.28 & 54.79 & 54.72 & 54.49 & 53.95 & 51.55 & 47.88 & 53.24 \\
\hline 99\% Paraffin & 55.28 & 54.70 & 54.63 & 54.56 & 54.10 & 51.70 & 48.02 & 53.28 \\
\hline Control & 55.28 & 54.04 & 53.62 & 53.50 & 52.54 & 49.66 & 46.59 & 52.17 \\
\hline Mean & 55.28 & 54.70 & 54.56 & 54.46 & 53.86 & 51.38 & 47.74 & \\
\hline L.S.D ${ }^{0.05}$ & \multicolumn{8}{|c|}{$(A)=0.32,(B)=0.28,(A \times B)=0.85$} \\
\hline
\end{tabular}

Ascorbic acid is the major antioxidant found in citrus fruits during storage. Vitamin $\mathrm{C}$ content of orange fruits reduced significantly in both waxed and unwaxed fruits, the degradation in ascorbic acid during storage was in accordance with the previous study of (Gardner et al., 2000). This degradation may be due to indirect loosestrife through polyphenol oxidase and peroxidase activity (Lee and Kader 2000). Manzano and Diaz (2001) mentioned that ascorbic acid is susceptible to oxidative deterioration results in the formation of dehydroascorbic acid.

Our results are in line with those of Kumar et al. (2000). In this respect, Shahid and Abbasi (2011) stated that the ascorbic acid content of fresh fruit was high just before ripening and then decreased due to the action of enzymes named ascorbic acid oxidase. This retention of ascorbic acid in coated fruits might be due to the depressing of respiration of fruits or decreased oxidation of ascorbic acid content from the fruits, on the other hand the lower content of ascorbic acid in untreated fruits might be due to higher respiration rate (Hassan et al., 2014).

Total soluble solids / acid ratio

Tables 15 and 16 declare that TSS/ acid ratio increased gradually with prolongation of cold storage period on orange fruits cv. Valencia in both seasons.

TABLE 15. Effect of different coatings on TSS /acid ratio of Valencia orange fruits during cold storage at $5^{\circ} \mathrm{C}$ in 2016 season.

\begin{tabular}{|c|c|c|c|c|c|c|c|c|}
\hline \multirow{2}{*}{ Treatment (A) } & \multicolumn{7}{|c|}{ Days of storage at $5^{\circ} \mathrm{C}$ (B) } & \multirow{2}{*}{ Mean } \\
\hline & $\mathbf{0}$ & 15 & 30 & 45 & 60 & 75 & 90 & \\
\hline $10 \%$ Bee wax & 8.04 & 8.05 & 8.08 & 8.14 & 8.18 & 8.27 & 8.37 & 8.16 \\
\hline $15 \%$ Bee wax & 8.04 & 8.14 & 8.14 & 8.18 & 8.21 & 8.25 & 8.26 & 8.18 \\
\hline $5 \%$ Gum arabic & 8.04 & 8.05 & 8.09 & 8.12 & 8.13 & 8.14 & 8.21 & 8.11 \\
\hline $10 \%$ Gum arabic & 8.04 & 8.07 & 8.12 & 8.14 & 8.17 & 8.19 & 8.23 & 8.14 \\
\hline $1 \%$ Chitosan & 8.04 & 8.06 & 8.13 & 8.15 & 8.19 & 8.21 & 8.31 & 8.16 \\
\hline $2 \%$ Chitosan & 8.04 & 8.07 & 8.16 & 8.19 & 8.17 & 8.21 & 8.20 & 8.15 \\
\hline $75 \%$ Paraffin & 8.04 & 8.06 & 8.14 & 8.18 & 8.21 & 8.29 & 8.42 & 8.19 \\
\hline 99\% Paraffin & 8.04 & 8.06 & 8.15 & 8.21 & 8.23 & 8.25 & 8.30 & 8.18 \\
\hline Control & 8.04 & 8.18 & 8.22 & 8.23 & 8.36 & 8.40 & 8.63 & 8.29 \\
\hline Mean & 8.04 & 8.08 & 8.14 & 8.17 & 8.20 & 8.25 & 8.32 & \\
\hline L.S.D ${ }^{0.05}$ & \multicolumn{7}{|c|}{$(A)=0.06,(B)=0.05,(A \times B)=0.15$} & \\
\hline
\end{tabular}

Egypt. J. Hort. Vol. 44, No.2 (2017) 
Untreated fruits showed the highest significant values of TSS/ acid ratio in both seasons, while $5 \%$ gum arabic showed the lowest value in the first season. Also, $2 \%$ chitosan and 5 or $10 \%$ gum arabic showed the lowest values in the second season.

At the end of storage period, control treatment showed the highest significant TSS/acid ratios
(8.63 and 8.42) in the first and second seasons respectively. While 2\% chitosan and 5\% gum arabic treatments showed the lowest significant ratios (8.20 and 8.21) respectively in the first season, whereas $10 \%$ gum arabic treatment showed the lowest ratio (8.26) in the second season.

TABLE 16. Effect of different coatings on TSS /acid ratio of Valencia orange fruits during cold storage at $5^{\circ} \mathrm{C}$ in 2017 season.

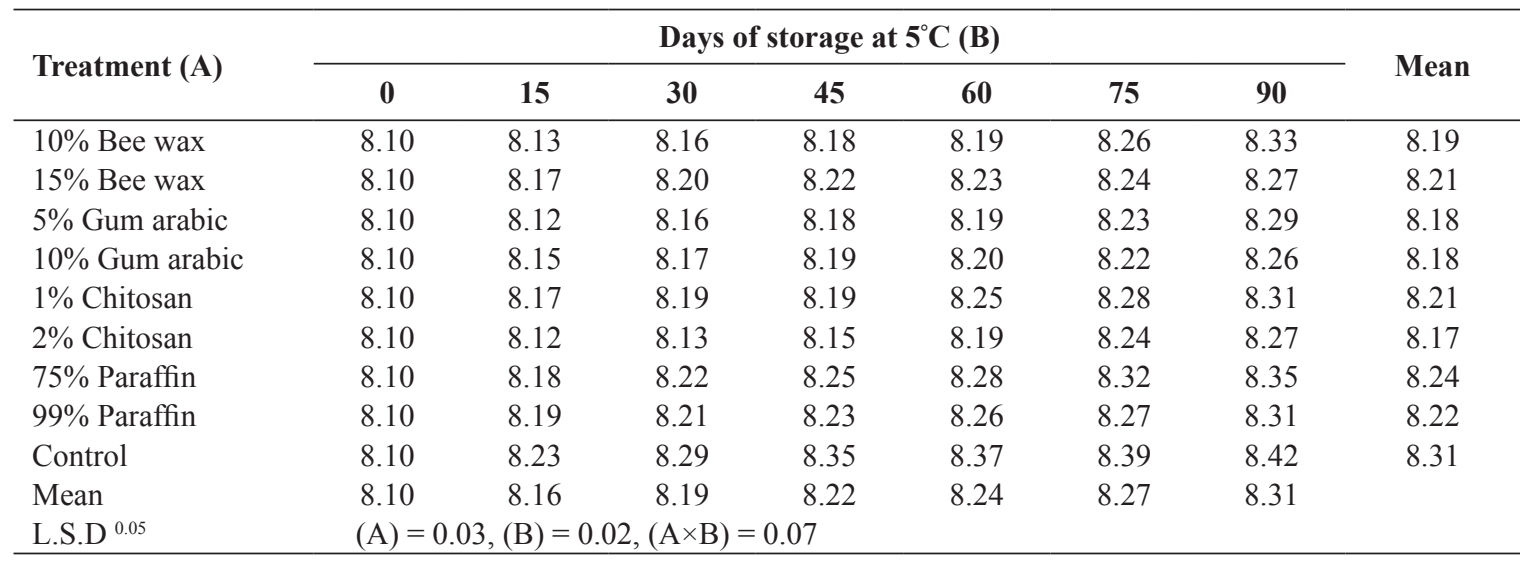

These results mean that the TSS increased and total acidity decreased during storage periods. As the ripening of the fruits develops, a reduction in titratable acidity is detected, the decrease in acid content occurred due to conversion of organic acids to form sugar (Baldwin et al., 1995). Similar findings were observed in some fruits treated with different coatings (Shahid and Abbasi, 2011), also Verma and Dashora (2000) found that TSS increased while ascorbic acid and acidity of Kagzi lime fruits decreased with prolongation of storage period. This increment in soluble solids in fruits is mainly correlated with the hydrolytic enzymes for starch, the developed activity of enzymes is responsible for the changes of starch to sugars. Also, deterioration of ascorbic acid lead to more TSS because of the chemical formula of ascorbic acid is related to glucose, so that reduction in ascorbic acid led to increase of glucose and higher TSS (Baldwin et al., 1999).

\section{Pectin methyl esterase activity (PME)}

Tables 17 and 18 present the effect of different coating materials on pectin methyl esterase activity of Valencia orange fruits during cold storage at $5^{\circ} \mathrm{C}$ in 2016 and 2017 seasons, PME activity decreased in the first 15 days compared to the initial sample, then it increased continuously with prolongation of cold storage in both seasons, untreated fruits showed the highest significant value in the first season, whereas the differences between the applied treatments were insignificant. At the end of storage period untreated fruits recorded the highest significant activity value (1.247), whereas chitosan at $2 \%$ treatment recorded the lowest significant activity (1.117).

Also, untreated fruits showed the highest significant value in the second season, whereas chitosan at $2 \%$ and gum arabic at $10 \%$ showed the lowest significant activities, after 90 days of storage period untreated ones and $10 \%$ bee wax treatment showed the highest significant values (1.218 and 1.213 respectively), whereas 2\% chitosan and $10 \%$ gum arabic treatments showed the lowest significant values (1.121 and 1.150 respectively).

The presented data illustrated advanced role of chitosan in delay PME activity, but it was insignificant compared with other coatings which might explained as indirect effect of coating compounds on enzyme and chemical progress. These results are in agreement with the outcome of Abu-Goukh and Bashir (2003). Also, the obtained data are in agreement with those obtained by Koslamind et al. (2005), who reported that PME activity in fruits was found to increase with the prolongation of storage period up to 2 months, Also, they found highest PME activity at the 
green phase when the fruit hardness was high and it declined as ripening advanced.

Protopectin is the source substance of pectin compounds that is hydrolyzed by the enzyme protopectinase into soluble product pectin, pectins are considered the basic substances involved in the mechanical strength of the primary cell wall and are vital to the physical structure of the plant (Sirisomboon et al., 2000).
The increment of PME activity might be duo to increase in pectin content due to the conversion of insoluble proto pectin into soluble pectin that acts as a substrate for PME enzyme because of that its activity increased. PME esterified pectic substances, making them exposed for polygalacturonase (PG) action (Wong, 1995).

TABLE 17. Effect of different coatings on pectin methyl esterase (PME) activity ${ }^{*}$ of Valencia orange fruits during cold storage at $5^{\circ} \mathrm{C}$ in 2016 season.

\begin{tabular}{lcccccccc}
\hline \multirow{2}{*}{ Treatment (A) } & \multicolumn{9}{c}{ Days of storage at $\mathbf{5}^{\circ} \mathbf{C}(\mathbf{B})$} & \multirow{2}{*}{ Mean } \\
\cline { 2 - 7 } & $\mathbf{0}$ & $\mathbf{1 5}$ & $\mathbf{3 0}$ & $\mathbf{4 5}$ & $\mathbf{6 0}$ & $\mathbf{7 5}$ & $\mathbf{9 0}$ & \\
\hline 10\% Bee wax & 1.065 & 0.931 & 1.010 & 1.062 & 1.124 & 1.131 & 1.167 & 1.070 \\
15\% Bee wax & 1.065 & 0.936 & 1.035 & 1.061 & 1.098 & 1.110 & 1.147 & 1.065 \\
5\% Gum arabic & 1.065 & 0.928 & 1.023 & 1.058 & 1.111 & 1.124 & 1.136 & 1.064 \\
10\% Gum arabic & 1.065 & 0.941 & 1.018 & 1.076 & 1.107 & 1.117 & 1.126 & 1.064 \\
1\% Chitosan & 1.065 & 0.940 & 1.016 & 1.076 & 1.097 & 1.112 & 1.139 & 1.064 \\
2\% Chitosan & 1.065 & 0.948 & 1.028 & 1.073 & 1.102 & 1.111 & 1.117 & 1.063 \\
75\% Paraffin & 1.065 & 0.954 & 1.014 & 1.075 & 1.103 & 1.107 & 1.143 & 1.066 \\
99\% Paraffin & 1.065 & 0.931 & 1.021 & 1.078 & 1.107 & 1.119 & 1.138 & 1.066 \\
Control & 1.065 & 1.029 & 1.045 & 1.084 & 1.137 & 1.146 & 1.247 & 1.108 \\
Mean & 1.065 & 0.949 & 1.023 & 1.071 & 1.109 & 1.120 & 1.151 & \\
L.S.D ${ }^{0.05}$ & $(\mathrm{~A})=0.019,(\mathrm{~B})=0.017,(\mathrm{~A} \times \mathrm{B})=0.051$ & & & & \\
\hline
\end{tabular}

${ }^{*}$ PME activity was defined as $\Delta \mathrm{A} 620 \mathrm{mg}^{-1}$ protein $\mathrm{min}^{-1}$

TABLE 18. Effect of different coatings on pectin methyl esterase (PME) activity* of Valencia orange fruits during cold storage at $5^{\circ} \mathrm{C}$ in 2017 season.

\begin{tabular}{|c|c|c|c|c|c|c|c|c|}
\hline \multirow{2}{*}{ Treatment (A) } & \multicolumn{7}{|c|}{ Days of storage at $5^{\circ} \mathrm{C}$ (B) } & \multirow{2}{*}{ Mean } \\
\hline & $\mathbf{0}$ & 15 & 30 & 45 & 60 & 75 & 90 & \\
\hline $10 \%$ Bee wax & 1.041 & 1.039 & 1.079 & 1.118 & 1.129 & 1.135 & 1.213 & 1.108 \\
\hline $15 \%$ Bee wax & 1.041 & 1.035 & 1.070 & 1.107 & 1.120 & 1.123 & 1.198 & 1.099 \\
\hline $5 \%$ Gum arabic & 1.041 & 0.986 & 1.030 & 1.064 & 1.078 & 1.084 & 1.156 & 1.063 \\
\hline 10\% Gum arabic & 1.041 & 0.964 & 1.025 & 1.052 & 1.072 & 1.079 & 1.150 & 1.055 \\
\hline 1\% Chitosan & 1.041 & 1.013 & 1.040 & 1.082 & 1.088 & 1.095 & 1.168 & 1.075 \\
\hline 2\% Chitosan & 1.041 & 0.940 & 0.984 & 1.036 & 1.037 & 1.103 & 1.121 & 1.037 \\
\hline $75 \%$ Paraffin & 1.041 & 1.017 & 1.049 & 1.087 & 1.098 & 1.105 & 1.178 & 1.082 \\
\hline 99\% Paraffin & 1.041 & 1.017 & 1.038 & 1.076 & 1.086 & 1.093 & 1.162 & 1.073 \\
\hline Control & 1.041 & 1.028 & 1.083 & 1.127 & 1.134 & 1.144 & 1.218 & 1.111 \\
\hline Mean & 1.041 & 1.004 & 1.044 & 1.083 & 1.094 & 1.107 & 1.174 & \\
\hline L.S.D 0.05 & $(A)=$ & $(B)=$ & , $(\mathrm{A} \times$ & .072 & & & & \\
\hline
\end{tabular}

${ }^{*}$ PME activity was defined as $\Delta \mathrm{A} 620 \mathrm{mg}^{-1}$ protein $\mathrm{min}^{-1}$ 


\section{Conclusion}

In conclusion, chitosan at $2 \%$ and paraffin at $99 \%$ showed the lowest significant weight loss values, Also chitosan at 2 or $1 \%$ and paraffin at $99 \%$ showed the lowest significant decay percentages. The different applied coatings significantly affected fruit respiration compared with control but the differences between coatings were insignificant. As well, gum arabic at $5 \%$ delayed the increment in TSS/ acid ratio compared with control. In addition, chitosan at 2 and $1 \%$ recorded the highest ascorbic acid contents after 90 days of $5^{\circ} \mathrm{C}$. Moreover, chitosan at $2 \%$ retained fruit firmness and maintained good fruit general appearance and colour. In other words, the physical and chemical parameters of fruits were significantly and positively influenced by chitosan at $2 \%$ up to 90 days of storage at $5^{\circ} \mathrm{C}$.

Acknowledgements: I gratefully acknowledge the assistance of Agricultural Systems Improvement Project and Cairo University Research Park.

Funding statements: This research was partially supported by Faculty of Agriculture, Cairo University, Egypt.

Conflicts of interest: The author has no conflicts of interest to declare.

\section{References}

A.O.A.C. (1980) "Official Methods of Analysis" $13^{\text {th }}$ ed. Association of official analytical chemists, Washington, D.C., USA.

Abu-Goukh, A.B. and Bashir, H.A. (2003) Changes in pectic enzymes and cellulase activity during guava fruit ripening. Food Chem., 83, 213-218.

Ali, Z.M., Chin, L.H. and Lazan, H. (2004) A comparative study on wall degrading enzymes, pectin modifications and softening during ripening of selected tropical fruits. Plant Sci., 167, 317-327.

Asgar, A., Mehdi, M., Senthil, R. and Peter, G.A. (2010) Gum arabic as a novel edible coating for enhancing shelf life and improving postharvest quality of tomato (Solanum lycopersicum L.) fruit. Postharvest Biology and Technology, 58, 42-47.

Baldwin, E.A., Niesperos, M.O., Shaw, P.E. and Burns, J.K. (1995) Effect of coatings and prolonged storage conditions on fresh orange flavour volatiles, degrees brix and ascorbic acid levels. Journal of Agricultural and Food Chemistry, 43 (5), 13211331.
Baldwin, E.A., Burns, J.K., Kazokas, W., Brecht, J.K., Hagenmaier, R.D., Benderd, R.J. and Pesis, E. (1999) Effect of two edible coatings with different permeability characteristics on mango (Mangifera indica L.) ripening during storage. Postharvest Biology and Technology, 17 (3), 215-226.

Chien, P.J., Sheu, F. and Lin, H.R. (2007) Coating citrus (Murcott tangor) fruit with low molecular weight chitosan increases postharvest quality and shelf life. Food Chem., 100, 1160-1164.

Del-Valle, V., Hernandez-Munoz, P., Guarda, A. and Galotto, M.J. (2005) Development of a cactusmusilage edible coating (opuntia Ficus indica) and its application to extend strawberry (Fragaria ananassa) shelf-life. Food Chem., 91, 751-756.

El-Anany, A.M., Hasan, G.F. and Ali, F.M. (2009) Effects of ediable coatings on the shelf-life and quality of Anna apple (Malus domestica B.) during cold storage. Journal of food technology. 7 (1), 5-11.

Gardner, P.T., White, A.C., McPhail, D.B., and Duthie, G.G. (2000) The relative contributions of vitamin $\mathrm{C}$, carotenoids and phenolic to the antioxidant potential of fruit juices. Food Chem., 68, 471-474.

Hassan, Z.H., Lesmayati, S., Qomariah, R. and Hasbianto, A. (2014) Effects of wax coating applications and storage temperatures on the quality of tangerine citrus (Citrus reticulata) var. Siam Banjar. International Food Research Journal., 21 (2), 641-648

Jeong, J., Huber, D.J., and Sargent, S.A. (2002) Influence of 1- methylcyclopropene (1-MCP) on ripening and cell wall matrix polysaccharides of avocado. Postharvest Biol. Technol., 25, 241-256.

Kader, A.A. (1992) Postharvest technology of horticultural crops. Univ. of Calif. Div. of Agriculture and Natural Resources Publication. pp.:15-20.

Koslamind, R., Archbold, D.D., and Pomper, K.W. (2005) Pawpaw fruits II. Acidity of selected cellwall degrading enzyme. Amer. J. Hort. Sci., 130, 643-648.

Kumar, J., Sharma, R.K., and Singh, R. (2000) The effect of different methods of packing on the shelf life of kinnow. J. Hort. Sci., 29, 202-203.

Lee, S.K., and Kader, A.A. (2000) Preharvest nd postharvest factors influencing vitamin $\mathrm{C}$ content of horticultural crops. Postharvest Biol. Technol., 20, 207-220. 
Mahajan, B.V., Bhatt, A.S., and Sandhu, K.S. (2005) Effect of different post harvest treatment on the storage life of kinnow. J. Food Sci. Technol., 42, 296-299.

Manzano, J.E., and Diaz, A. (2001) Effect of storage time, temperature and wax coating on the quality of fruits of 'Valencia' orange (Citrus sinensis L.). Proc. Int. Soc. Trop. Hort., 44, 24-29.

Mazumdar, B. and Majumder, K. (2003) Methods on Physico-chemical Analysis of Fruits, Daya Publ. House, Delhi, India, 93-139.

McGuire, R.G. (1992) Reporting of objective color measurements. Hort. Science, 27, 1254-1255.

McGuire, R.G. (1997) Market quality of guava after hot water treatment and application of carnauba wax coating. Hortic Sci., 32, 271-274

McCollum, T.G., D’ Aquino, S., and McDonald, R.E. (1993) Heat treatment inhibits mango chilling injury. Hort. Science, 28 (3), 197-198.

Miranda, S.P., Garnica, O., Lara-Sagahon, V., and Cárdenas, G. (2004) Water vapor permeability and mechanical properties of chitosan composite films. J. Chil. Chem. Soc., 49, 173-178.

Mitcham, B., Cantwell, M. and Kader, A.A. (2003) Method for determining quality of fresh commodities. Pershiables Handling Newsletter Issue No.85.

Motlagh, S., Ravines, P., Karamallah, K.A., and Ma, Q. (2006) The analysis of Acacia gums using electrophoresis. Food Hydrocol., 20, 848-854.

Nambi, V.E., Thangavel, K., Shahir, S. and Geetha, V. (2015) Evaluation of colour behavior during ripening of Banganapalli mango using CIE-Lab and RGB colour coordinates. Journal of Applied Horticulture, 17(3), 205-209.

Park, H.J. (1999) Development of advanced edible coatings for fruits. Trends in Food Science \& Technology, 10 (8), 254-260.

Porat, R., Weiss, B., Cohen, L., Daus, A., and Biton, A. (2005) Effects of polyethylene wax content and composition on taste, quality, and emission of offflavor volatiles in Mor mandarin. Postharvest Biol Technol., 38, 262-268.

Porta, R., Rossi-Marquez, G., Mariniello, L., Sorrentino, A., and Giosafatto, V. (2013) Edible coating as packaging strategy to extend the shelflife of fresh-cut fruits and Vegetables. J. Biotechnol Biomater, 3(4), 124-126.
Saftner, R.A. (1999) The potential of fruit coating and treatment for improving the storage and shelf life qualities of Gala and Golden delicious apples. Journal of the American Society for Horticultural Science, 124 (6), 682-689.

Salman, M., Anwar, J., Zaman, W., Shafique, M. and Irfan, A. (2008) Preparation of oil / water emulsions of paraffin and bees waxes with water. Journal of Scientific Research, 38 (2), 5-8.

Shahid, M.N. and Abbasi, N.A. (2011) Effect of bee wax coatings on physiological changes in fruits of sweet orange CV. "Blood Red". Sarhad Journal of Agriculture, 27 (3), 385-394.

Shein, N.N., Jaroenkit, T., Ussahatanonta, S. and Jarassamrit, N. (2008) Effect of wax coating on the postharvest quality of 'Sai Nam Peung' mandarin orange (Citrus reticulata B.). Agricultural Science Journal, 39 (3), 13-16.

Singh, U.B., Shafaat, M., and Dashora, L.K. (1997) Comparative efficacy of wax emulsion and rice starch on the post harvest shelf life of fully ripe guava fruits. J Food Sci Technol., 34, 519-522.

Sirisomboon, P., Tanaka, M., Fujita, S., and Kojima, T. (2000) Relationship between the texture and pectin constituents of Japanese pear. J Texture Stud., 31, 679-690.

Snedecor, G.W. and Cochran, W.G. (1989) Statistical Methods, $8^{\text {th }}$ ed. lowa State Univ. press, Ames, lowa, USA, $507 \mathrm{p}$.

Tendaj, B. and Tendaj, M. (1998) Waxes as components of protective films and coatings for fresh fruits and vegetables. Post. Nauk Roln., 1, 79-90.

Tietel, Z., Bar, E., Lewnsohn, E., Feldmeser, E., Falik, E. and Porat, R. (2010) Effects of wax coatings and postharvest storage on sensory quality and aroma volatile composition of 'Mor' mandarins. Journal of the Science of Food and Agriculture., 90 (6), 995-1007.

Verma, P., and Dashora, L.K. (2000) Post-harvest physiconutritional changes in Kagzi Limes (Citrus aurantifolia $\mathrm{S}$.) treated with selected oil emulsions and diphenyl. Plant Food Hum Nut., 55, 279-284.

Wong, D.W. (1995) Pectic enzymes. Food enzymes. Structure and mechanisms. New York, Chapman and Hall. pp. 212-236.

(Received 03/12/2017, accepted 18/01/2018) 
هل تختلف جودة البرتقال صنف الفالنشيا كاستجابة لمواد التشميع المختلفة أثناء التخزين

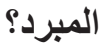

عماد الدين حمدى خضر

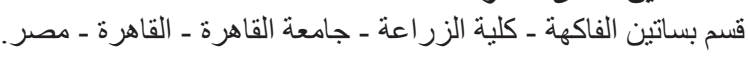

نظر الأهمية عملية التشميع في ثمار البرتقال الفالنشيا وخاصة المعدة للتصدير هدفت تلأك الدراسة الى تقييم

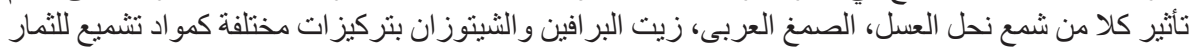

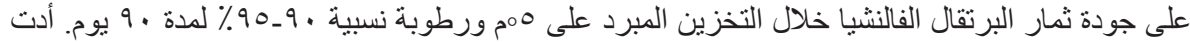

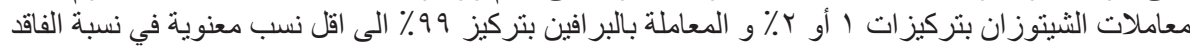

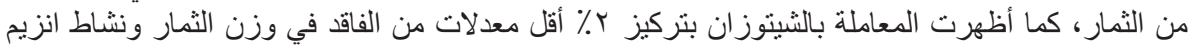

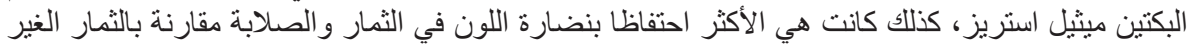

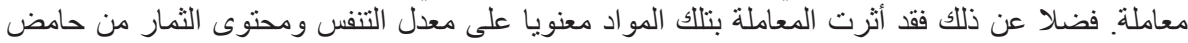

الاسكوربيك مقارنة بتلك الغير معاملة. 